\title{
FAMILY BUSINESS IN THE LIGHT OF THE CORPUS AND THE CZECH LAW
}

\author{
[Rodinné podnikání ve světle korpusu a českých zákonů] \\ Milan Hnátek ${ }^{1}$, Milena Hnátková ${ }^{2}$ \\ ${ }^{1}$ Univerzita Tomáše Bati ve Zlíně, Fakulta managementu a ekonomiky, Mostní 5139, 760 01, Zlín \\ Email:mhnatek@fame.utb.cz \\ ${ }^{2}$ Karlova univerzita v Praze, Filozofická fakulta, Ústav teoretické a komputační lingvistiky, \\ Celetná 13, 11000 Praha 1 \\ Email: milena.hnatkova@ff.cuni.cz
}

\begin{abstract}
This paper focuses on the new terminology used in the new Czech Civil Code, which is in force from January 1, 2014. This new Civil Code completely changes the Czech legal system by introducing a totally new terminology. The paper deals with this new terminology which defines family businesses; this terminology is unfortunately different from the terminology having been used for many years. The new Civil Code introduces a new term "rodinný závod" which evokes "family race" instead of the intended term "family business" in Czech. The objective of the paper is to examine this new Civil Code by means of linguistic tools and to focus on the future problems which may occur due to the introduction of the new term. The paper combines different techniques of linguistic research and family business research. In the introduction, the authors deal with the definitions of the new terms and explain the importance of the research. Then an overview of legal conditions of family business in the Czech Republic is presented. In the central part, the problem under investigation is described and the results of the research is presented. In the conclusion, the authors summarize their new findings.
\end{abstract}

Keywords: business law, civil code, family business, linguistics.

JEL classification: K20, K36

Doručeno redakci: 13.11.2013; Recenzováno: 12.5.2014; 14.5.2014; Schváleno k publikování: 23.9.2014

\section{Úvod}

Článek navazuje na předešlý článek s názvem Využití metod jazykovědy při výzkumu rodinného podnikání v České republice, ve kterém autoři (Hnátek, Hnátková, 2013, s. 213-224) poprvé představili, jakým způsobem lze při výzkumu rodinného podnikání využít lingvistické metody zkoumání (automatickou analýzu textu). Jedná se o velice zajímavou aplikaci a jen to potvrzuje fakt, že výzkum rodinného podnikání je velice komplexní obor a vyžaduje mezioborovou spolupráci. Autoři se ve svém předchozím článku (Hnátek, Hnátková, 2013, s. 213-224) na rodinné podnikání podívali jako na socioekonomický fenomén a soustředili se na zmapování a rozšíření terminologie spojené s rodinným podnikáním. Výzkum byl postaven na teorii, že pokud se rodinné podnikání a jeho problematika stává fenoménem posledních let, bude se o něm ve zvýšené míře psát v odborném periodiku a stane se předmětem zájmu novinářů a odborné veřejnosti. Pro ověření této teorie o rostoucím trendu byl vytvořen korpus elektronických textů Hospodářských novin z let 1997 - $2010(\mathrm{HN})$, který byl zpracován metodami korpusové lingvistiky - především automatickým vyhledáváním slovních spojení a termínů. Korpus je Českým národním korpusem (ČNK, 2014) definován jako soubor počítačově uložených textů, který slouží k jazykovému výzkumu. K práci s tímto korpusem slouží speciální vyhledávací program. S jeho pomocí je možné vyhledávat slova a slovní spojení v kontextu a zjistit jejich frekvenci v korpusu i původní textový zdroj. U některých korpusů lze vyhledávat podle slovních druhů a dalších gramatických kategorií. Autoři (Hnátek, Hnátková, 2013, s. 213-224) potvrdili, 
že oblast rodinného podnikání se dostává do popředí zájmu, když se $\mathrm{v}$ jednotlivých letech 1997 až 2010 v sukorpusu Hospodářských novin zvyšuje frekvence výskytu termínu rodinný podnik a rodinná firma. Je tedy zřejmé, že se o rodinném podnikání více píše a tím se tedy stává aktuálním tématem, kterým se média zabývají.

\section{Rodinné podnikání}

Rodinné podnikání má v České republice historickou tradici, která však byla na dlouhá desetiletí přerušena obdobím plánovaného hospodářství a socialistickým zřízením. Na tradici rodinného podnikání bylo v České republice možno navázat až po roce 1989, kdy ekonomika prošla transformací a bylo opět umožněno soukromé podnikání. V České republice, podobně jako v jiných vyspělých ekonomikách, je rodinné podnikání hnací silou ekonomiky, avšak dle Poledny a Polednové (2008) v České republice nejsou dostupná přesná data o počtu rodinných podniků. Rodinné podniky na rozdíl od malým a středním podnikům, které mají v Evropské unii jednoznačnou a obecně uznávanou definici, se potýkají se situací, že je velice obtížné rodinné podniky definovat. $\mathrm{V}$ českých podmínkách jsou rodinné podniky řazeny $\mathrm{v}$ kategorii malých a středních podniků. Pravděpodobně je to způsobeno poměrně krátkou historií nově vzniklých českých rodinných podniků, které nestihly vyrůst do nadnárodních holdingů, jak je tomu např́klad v Turecku (Sabancı Holding, Koç Holding) nebo v USA (Walmart, Ford). Tato kategorizace prozatím stačí, ale jakmile české rodinné podniky překročí určitou velikost (počet zaměstnanců, obrat, celková bilance), nebude možné rodinné podniky nijak podrobně sledovat. Podle Poledny a Polednové (2008) se podíl rodinných podniků v evropských ekonomikách pohybuje mezi 80 - 90 \%. Na základě jejich úvah (Poledna, Polednová, 2008) se procento rodinných podniků $\mathrm{v}$ české ekonomice pohybuje na horní hranici tohoto rozpětí. Hnátek (2012b) uvádí, že hlavním důvodem, proč česká ministerstva a další státní instituce vůbec rodinný podnik nerozpoznávají a nepodporují, je problém rozlišení rodinného podniku od ostatních kategorií a forem podniku. Tyto zmíněné státní instituce na základě výzkumu (Hnátek, 2012b) uvádějí jako důvod tohoto problému chybějící definici rodinného podnikání a chybějící přesnou charakteristiku rodinného podniku, která by byla všeobecně uznávána. Rodinné podnikání tak doplácí na to, že stále chybí jednotná a obecně používaná definice rodinného podniku, resp. rodinné firmy. Jak se již ukázalo, je problematika rodinného podnikání velice aktuální. To také mimo jiné potvrzuje nový Občanský zákoník platný od 1. ledna 2014, který zavedl nový pojem ,rodinný závod“. V České republice doposud nebylo rodinné podnikání upraveno zákonem a po dlouhá léta byl význam rodinných podniků velmi podceňován.

Rodinné podnikání má velmi mnoho podob, a proto se pro popsání této specifické ekonomické jednotky lépe hodí označení rodinný podnik, které v sobě zahrnuje všechnu různorodost a formy rodinného podnikání. Mezi nejčastější formy rodinných podniků patří partnerské rodinné podniky, ve kterých spolu pracují manželé nebo životní partneři. Př́kladem jiné formy rodinných podniků jsou podniky, ve kterých spolu pracují dvě generace, a to rodiče se svými potomky. Jak říká Hnátek (2012a), takovým rodinným podnikem může být jak malá soukromá dílnička, ve které pracuje otec se svým synem, tak také nadnárodní holding, který je již po několik generací řízen a vlastněn členy jedné rodiny. Mezi nejznámější rodinný klan bezesporu patří americká rodina Rockefellerů, nebo v českých podmínkách známá rodina Bat'ù. Vyskytují se zde však i další formy rodinných podniků, kde spolu v podniku pracují sourozenci, švagři atd. Rodina se také může na podnikání přímo podílet nebo podnik jen vlastnit a jeho řízení přenechat najatým managerům. Poledna a Polednová (2008) mluví o rodinném podniku jako o firmě, která je vlastněna jednou nebo více rodinami, a jejíž řízení a vlastnictví je předáváno z generace na generaci. Tato definice se tak neomezuje pouze na členy jedné rodiny, ale může být ř́zena a vlastněna více rodinami. $\mathrm{V}$ této definici se 
tedy také vyskytuje prvek vlastnictví, které je předáváno z generace na generaci. Asociace malých a středních podniků a živnostníků ČR (AMSP ČR, 2013) hovoří o tom, že rodinná firma je taková firma, kde většina vlastnických práv nebo kontrola a rozhodování je v rámci rodiny. Dále pak, že alespoň jeden z rodinných př́slušníků se př́imo podílí na chodu firmy. Tato definice pak hovoří prŕímo o firmě a odchyluje se tak od obecnějšího pojmu podnik.

\section{Legislativní úprava rodinného podnikání}

Posun v nedostatečném ošetření rodinného podnikání zákonem nastal s novým Občanským zákoníkem, který rekodifikuje české soukromé právo a nahrazuje nejen dosavadní občanský zákoník, ale i mnoho dalších právních předpisů. Nový Občanský zákoník má 3081 paragrafů, 238 dosavadních předpisů bylo zrušeno a 130 jich bylo novelizováno. Ošetření rodinného podnikání zákonem však bylo poněkud nešt’astné, jelikož Občanský zákoník (Zákon č. 89/2012 Sb.) zavádí v $§ 700$ až $§ 707$ do již komplikované terminologie zcela nový pojem „závod" potažmo ,rodinný závod“.

Podnikatelem dle $\S 420$ Občanského zákoníku (Zákon č. 89/2012 Sb.) je ten, kdo samostatně vykonává na vlastní účet a odpovědnost výdělečnou činnost živnostenským nebo obdobným způsobem se záměrem činit tak soustavně za účelem dosažení zisku. Ale pro účely ochrany spotřebitele a pro účely $\S 1963$ se podle $\S 420$ dále za podnikatele považuje také každá osoba, která uzavírá smlouvy související s vlastní obchodní, výrobní nebo obdobnou činností či při samostatném výkonu svého povolání, popř́padě osoba, která jedná jménem nebo na účet podnikatele. § 421 Občanského zákoníku (Zákon č. 89/2012 Sb.) pak dále ř́ká, že se za podnikatele považuje osoba zapsaná v obchodním rejstř́íku. Jméno, pod jakým je podnikatel zapsán do obchodního rejstříku, je pak podle $\S 423$ obchodní firma. Pojmenování rodinná firma je tedy $\mathrm{v}$ současném právu definováno pouze jako jméno (název), než pojem popisující podobu formy podnikání. K rozšîření tohoto pojmenování nepřispívá ani v češtině používané slovní spojení, že je někdo známá firma, čímž se myslí někdo, kdo je znám spíše v negativním smyslu.

Nový Občanský zákoník (Zákon č. 89/2012 Sb.) v § 502 uvádí, že závod je organizovaný soubor jmění, který podnikatel vytvořil a který z jeho vůle slouží k provozování jeho činnosti. Má se za to, že závod vytváří vše, co zpravidla slouží k jeho provozu. Občanský zákoník (Zákon č. 89/2012 Sb. § 700, odst 1) mino jiné hovoří, že za rodinný se považuje závod, ve kterém společně pracují manželé nebo alespoň s jedním z manželů i jejich př́ibuzní až do třetího stupně nebo osoby s manžely sešvagřené až do druhého stupně a který je ve vlastnictví některé z těchto osob. Na ty z nich, kteří trvale pracují pro rodinu nebo pro rodinný závod, se hledí jako na členy rodiny zúčastněné na provozu rodinného závodu. Kyselová (2013) objasňuje, že rodinný závod můžeme charakterizovat jako speciální typ obchodního závodu, jak ho upravuje nový občanský zákoník dříve nazýván "podnik", jak ho upracoval obchodní zákoník. Dle zákonné definice obchodního závodu se jedná o „organizovaný soubor jmění, který podnikatel vytvořil, a který z jeho vưle slouží k provozování jeho činnosti”. Nelze ho tedy považovat za právní subjekt, nýbrž z hlediska právní teorie za věc hromadnou (Kyselová, 2013).

Rodinný závod tedy laicky řečeno vzniká všude tam, kde si členové jedné rodiny vzájemně neformálně vypomáhají, a dává zúčastněným osobám jistá práva a ochranu i pro př́pad prodeje či jiné dispozice s rodinným závodem. Kyselová (2013) uvádí, že důvodem zařazení bylo odbourání smluvní povinnosti u osob, které fakticky pracují pro rodinu, nebo se nějak podílejí na jejím fungování. Tato úprava rodinného závodu byla převzata z italského Codice Civil. Důvody této inspirace se nepodařilo zjistit, ale dá se předpokládat, že v Itálii, kde má 
rodina velkou váhu a práce rodinných př́slušníků pro rodinný podnik je běžná, vzniká potřeba práci rodinných príslušníků právně ošetřit.

Z pohledu zavedené praxe a jazykového úzu je vhodnější pojem rodinný podnik, kdy nařízení Evropské komise (Úřední věstník Evropské unie, 2008) za podnik považuje každý subjekt vykonávající hospodářskou činnost, bez ohledu na jeho právní formu. K těmto subjekti̊m patří zejména osoby samostatně výdělečně činné a rodinné podniky vykonávající řemeslné či jiné činnosti a obchodní společnosti nebo sdružení, která běžně vykonávají hospodářskou činnost. Dříve byl podnik Obchodním zákoníkem (Zákon č. 513/1991 Sb., § 5) definován jako soubor hmotných, jakož i osobních a nehmotných složek podnikání. K podniku náležely věci, práva a jiné majetkové hodnoty, které patřily podnikateli a sloužily k provozování podniku nebo vzhledem k své povaze měly tomuto účelu sloužit. Podle těchto definic je podnikem obecně označováno všechno, co podnikatel potřebuje ke své podnikatelské činnosti a dosažení zisku. Podnikem tak může být osoba nebo i obchodní společnost. Pojem podnik tak označuje jak obchodní společnost, tak i podnikatele podnikajícího na živnostenský list. Podle Zákona o obchodních korporacích (Zákon č. 90/2012 Sb.) jsou obchodní společnosti označovány nově jako obchodní korporace, čímž se zavádí další termín, na jehož používání si musí podnikatelé, právníci a občané zvyknout, přijmout ho a začít používat.

Úřad pro ochranu hospodářské soutěže a Ministerstvo zemědělství za účelem lepší orientace poskytovatelů, ale také př́ijemců podpory de minimis vypracovalo př́ručku (Ministerstvo zemědělství, 2014), ve které hovoří o pojmu "jeden podnik". Tímto termínem tak nepřímo odkazuje na neexistující definici, ale na všeobecně zavedený termín podnik. Pojem "jeden podnik" je touto př́ručkou doslova definován jako jakýkoliv subjekt vykonávající hospodářskou činnost nezávisle na právním postavení tohoto subjektu a způsobu jeho financování. Z tohoto tedy jednoznačně vyplývá snaha zahrnout do definice co nejvíce podnikatelských subjektů. To znovu ukazuje, že pojmenování rodinná firma nebo rodinný závod tvoří jen výseč a že pojmenování rodinný podnik je mnohem všeobjímající.

\section{Výzkumný problém}

Jak již bylo uvedeno, autoři se v předešlém výzkumu (Hnátek, Hnátková, 2013, s. 213 - 224) mimo jiné soustředili na porovnání výskytu pojmenování rodinná firma a rodinný podnik v textech Hospodářských novin v letech 1997 až 2010. Jako výsledek výzkumu se potvrdilo, že se v těchto textech obecně zvyšuje frekvence obou těchto zkoumaných pojmů. Dalo by se tedy říci, že se o rodinném podnikání více píše. Ukázalo se, že v uvedeném ekonomickém tisku převládá označení rodinná firma. Nový občanský zákoník platný od 1. ledna 2014 pak zavádí zcela nový pojem rodinný závod. Zavedení tohoto pojmu do odborné terminologie je poněkud zavádějící a nevhodné. Podstatou výzkumného problému, jehož řešením se autoři tohoto článku zabývají, je pak praktické užívání, resp. neužívání, nového pojmu rodinný závod v psaném textu. Pro svůj výzkum využívají lingvistické metody zkoumání, konkrétně automatickou analýzu elektronických českých publicistických textů, programem automatického vyhledávání ustálených slovních spojení v morfologicky označkovaném textu a vytvořením př́slušných frekvenčních seznamů.

\section{Výsledek zkoumání}

Ve Slovníku spisovného jazyka českého (SSJČ, 1989) je pojmenování ,firma“ také uvedeno jako název podniku - vývěsní štít s označením podniku nebo podnik sám (zpravidla velký), přeneseně hanlivě: ,,známá firma“ - člověk známý nepoctivostí; , vykřičená firma “ - člověk špatné pověsti. Slovo „podnik“ je zde definováno jako „,závod“, zařízení sloužící potřebám veřejnosti, právní a hospodářská jednotka, jejímž prostřednictvím se provozuje určitá 
hospodářská činnost. První význam slova závod v SSJČ je útvar, jednotka provozující určitou hospodářskou činnost, ve druhém významu je závod měření sil, soutěžení několika soupeřu usilujících o prvenství (v cíli), o vítězství.

Ve zmíněném korpusu Hospodářských novin, který byl zkoumán v předešlém článku (Hnátek, Hnátková, 2013, s. 213 - 224), obsahujícím 183 milionů slov se přitom pojmenování „, rodinný závod" nevyskytlo ani v jednom významu.

Ústav českého národního korpusu zveřejnil nový korpus publicistiky za posledních pět let, který obsahuje skoro jednu miliardu slov. Zde se slovní spojení „,rodinný závod“ vyskytuje celkem 30 krát, ale ve významu rodinného závodu jako hospodářského subjektu jsou z toho pouze tyto čtyři výskyty:

(1) $V$ červnu zahynulo $v$ této provincii deset lidí při výbuchu $v$ rodinném závodě na dynamit ...

(2) I když se dveře v rodinném závodě začaly vyrábět až na sklonku první republiky, dnes patři firma $k$ "jedničkám"...

(3) Spolumajitel Sapeli Jindřich Procházka se narodil přimo v areálu polenského rodinného závodu, kde tehdy fungovala pila, škrobárna a truhlárna.

(4) ... ř rkl Václav Hofmeister při prohlídce rodinného závodu na Borských polích v Plzni.

Ostatní výskyty slovních spojení „,rodinný závod“ jsou v tomto korpusu pouze jako oznámení o konání sportovní akce, které se účastní celé rodiny. Pro srovnání, přitom slovní spojení „, rodinná firma/firmička“ se v tomto množství dat vyskytuje celkem 1995 krát, slovní spojení „,rodinný podnik/podnikáni““ je zde uvedeno 1243 krát.

Tabulka 1: Frekvence výskytů slovních spojení v korpusech ČNK

Synchronní publicistické korpusy

\begin{tabular}{|c|c|c|c|c|c|c|}
\hline Název & $\begin{array}{c}\text { rodinný závod } \\
\text { (celkem) }\end{array}$ & $\begin{array}{c}\text { rodinný závod } \\
\text { (podnik) }\end{array}$ & $\begin{array}{c}\text { rodinný } \\
\text { podnik }\end{array}$ & $\begin{array}{c}\text { rodinný } \\
\text { podnik* }\end{array}$ & rodinná firma & rodinná firma \\
\hline syn2006pub & 5 & 1 & 412 & 1,37 & 439 & 1,46 \\
\hline syn2009pub & 10 & 0 & 756 & 1,08 & 1064 & 1,52 \\
\hline syn2013pub & 30 & 4 & 1161 & 1,24 & 1984 & 2,12 \\
\hline
\end{tabular}

* frekvence přepočtené na milión slov

Zdroj: vlastní zpracování

$\mathrm{V}$ tabulce 1 jsou uvedeny konkrétní frekvence výskytů slovních spojení rodinný závod, rodinný podnik a rodinná firma v korpusech syn2006pub (korpus publicistických textı̊ z let 1984 - 2004, velikost 300 miliónů slov), syn2009pub (korpus publicistických textů z let 1995 - 2007, velikost 700 miliónů slov) a syn2013pub (korpus publicistických textů z let 2005 - 2009, velikost 935 miliónů slov). Z uvedených údajů je zřejmé, že pojem rodinný závod se jako pojmenování rodinného podnikání skoro nepouživá, naopak se zvyšuje frekvence používání pojmu rodinná firma.

Podíváme-li se na novou legislativu (Občanský zákoník, Zákon č. 89/2012 Sb.) očima běžného podnikatele - vlastníka rodinného podniku, resp. rodinné firmy, dostal se po účinnosti nového Občanského zákoníku do situace, kterou můžeme charakterizovat 
ustáleným rčením „čert aby se v tom vyznal“. V dnešní době masivního rozšíření počítačů a hledání informací na internetu pro běžného uživatele, který není dostatečně obeznámen $\mathrm{s}$ přesným pojmoslovím v novém Občanském zákoníku, nastanou problémy. Tento uživatel bude přirozeně vyhledávat informace o rodinném podniku nebo rodinné firmě a paradoxně se předně nedozví o legislativních úpravách, týkajících se rodinného podnikání. Je však jisté, že se vyhledávače stále zdokonalují a stávají se sofistikovanějšími, takže pravděpodobně dříve nebo později uživateli dodají potřebnou informaci. Slovní spojení rodinný závod vešlo do podvědomí lidí jako prospěšná nebo zábavná činnost, organizovaná pro rodiny s dětmi, proto výsledek vyhledávání na internetu prímo nově zavedeného pojmu ,rodinný závod" bude obsahovat mnoho ,,smeti” v podobě oznámení o konání různých závodů. V neposlední řadě existuje stále přetrvávající asociace, že závody byly přece státní a národní podniky v období „reálného socialismu”.

Vyhledávání pojmu "rodinný závod" na internetu sice dává nesrovnatelně více výsledků (například ve vyhledávači Google - 793 tisíc nálezů spojení rodinný závod), dokonce první výskyty se týkají pojmenování rodinného závodu jako předmětu rodinného podnikání. Tento výsledek je způsoben dobrým "nastavením" vyhledávače a jeho řazením výsledků podle konkrétních aktuálních témat, ale ne podle frekvence užití termínu. Ve vyhledávači je zcela nemožné odfiltrovat počet nálezů, které se týkají pouze rodinných soutěží. Dále výskyt termínu na internetu neodráží aktuální jazykový úzus, protože většina zveřejněných dokumentů jsou encyklopedické, slovníkové a archivní informace, prrípadně právní a vědecké pojednání a vysvětlující odpovědi na dotazy uživatelů, kteří se s pro ně neznámými pojmy setkají. Lidé ale běžně tyto termíny nepoužívají a ani se $\mathrm{s}$ nimi nikde jinde než $\mathrm{v}$ právních dokumentech nesetkají.

\section{Závěr}

Předmětem zájmu autorů tohoto článku byl pojem rodinný závod, který se nově vyskytuje v novém Občanském zákoníku (Zákon č. 89/2012 Sb.), který platí od 1. ledna 2014. Autoři článku svým výzkumem chtěli především poukázat na zjevný rozpor ve skutečně doposud používaných pojmenováních, které se neshodují s nově zavedeným termínem "rodinný závod". Dle předešlých zjištění je problematika rodinného podnikání v České republice aktuálním tématem a $\mathrm{v}$ posledních letech nabývá její řešení na důležitosti. Jedinečnost tohoto článku spočívá $\mathrm{v}$ tom, že $\mathrm{v}$ sobě spojuje pohled na rodinné podnikání v nové legislativě (Občanský zákoník, Zákon č. 89/2012 Sb.) z hlediska ekonomie a také jazykovědy. Autoři článku tak zkoumali pojmenování rodinný závod v kontextu zavádění v novém Občanském zákoníku a praktického užívání, resp. neužívání, tohoto nového termínu v psaném textu.

V předchozích výzkumech (Hnátek, Hnátková, 2013, s. 213 - 224) se potvrdilo, že se ve zkoumaných textech zvyšuje frekvence výskytu pojmů rodinný podnik a rodinná firma, což znamená, že se o rodinném podnikání více píše a dostává se do popředí zájmu. V těchto textech se však nevyskytuje pojem rodinný závod, což ukazuje, že pojmenování použitá v novém Občanském zákoníku (Zákon č. 89/2012 Sb.) se liší od ustálených slovních spojeních skutečně používaných v tisku a odborné literatuře. Toto může zejména $\mathrm{v}$ začátcích vést k problémům.

Autoři tak chtějí zdůraznit, že s novým Občanským zákoníkem (Zákon č. 89/2012 Sb.) se musí nejen předně seznámit odborná veřejnost, zahrnující např́íklad právníky, soudce a poradenské agentury, ale hlavně je třeba vyvinout značné úsilí, aby byla $s$ novou právní úpravou seznámena široká veřejnost. Cílem by nemělo být ani tak seznámení s přesným zněním a výkladem jednotlivých paragrafi̊, ale hlavně se zavedením nového pojmosloví, používaného v novém zákoníku. 


\section{Poděkování}

Tento př́spěvek byl zpracován jako jeden z výstupů projektu financovaného Interní grantovou agenturou FaME UTB, č. IGA/FaME/2012010 „Výzkum přístupů k plánování nástupnictví v malých a středních rodinných podnicích“.

\section{Literatura}

[1] AMSP ČR, Rodinné firmy v ČR, 2013. Asociace malých a středních podniků a živnostniků $\check{C} R$ [online]. 12. června 2013 [vid. 6. listopadu 2013] Dostupné z: http://www.amsp.cz/uploads/RODINNA_FIRMA_ROKU_Pruzkum_AMSP _FINAL1.pdf

[2] ČESKÝ NÁRODNÍ KORPUS (ČNK), 2013. Ústav Českého národního korpusu FF UK [online]. [vid. 30. ř́ijna 2013]. Dostupné z: http://www.korpus.cz

[3] HNÁTEK, M., 2012a. Limitations of defining a family business. In: 8. ročník Mezinárodni Batovy konference pro doktorandy a mladé vědecké pracovníky. Zlín: UTB ve Zlíně. ISBN 978-80-7454-013-4.

[4] HNÁTEK, M., 2012b. Analýza př́istupu českých státních institucí k rodinným podnikům. In: Manažment podnikania a vecí verejných - Zborník vedeckých prac, 2(2), 138-145.

[5] HNÁTEK, M. a M. HNÁTKOVÁ, 2013. Využití metod jazykovědy při výzkumu rodinného podnikání v České republice. In: Mezinárodní vědecká konference Hradecké ekonomické dny 2013 Ekonomický rozvoj a management regionů. ISBN 978-80-7435249-2.

[6] KYSELOVÁ, T., 2013. Rodinný závod - další z novinek v novém Občanském zákoníku. epravo.cz, a.s. [online]. 25. ledna 2013 [vid. 22. června 2013]. Dostupné z: http://www.epravo.cz/top/clanky/rodinny-zavod-dalsi-z-novinek-v-novemobcanskem-zakoniku-88352.html

[7] Metodická prŕručka $\mathrm{k}$ aplikaci pojmu ,jeden podnik“ $\mathrm{z}$ pohledu pravidel podpory de minimis. Ministerstvo zemédelství [online]. 22. června 2014 [vid. 22. června 2014]. Dostupné z: http://eagri.cz/public/web/file/306030/Prirucka_k_pojmu_jeden_podnik.pdf

[8] Nařizení komise (ES) č. 800/2008 ze dne 6. srpna 2008, Příloha 1. Úřední věstník Evropské unie [online]. 9 srpna 2008 [vid. 2. července 2013]. Dostupné z: http://eurlex.europa.eu/LexUriServ/LexUriServ.do?uri=OJ:L:2008:214:0003:0047:cs:PDF

[9] POLEDNA, J. a M. POLEDNOVÁ, 2008. Overview of Family Business Relevant Issues, Country Fiche Czech Republic. Austrian Institute for SME Research [online]. [vid. 22. června 2013]. Dostupné z: http://ec.europa.eu/enterprise/policies/sme/files/craft/family_business/doc/familybusines _country_fiche_czech_republic_en.pdf

[10] SLOVNÍK SPISOVNÉHO JAZYKA ČESKÉHO (SSJČ). 1989. Lexikografický kolektiv Ústavu pro jazyk český ČSAV, 2. vydání

[11] Zákon č. 513/1991 Sb., Obchodní zákoník. Ministerstvo vnitra [online]. [vid. 2. července 2013]. Dostupné $\quad \mathrm{z}$ : http://portal.gov.cz/app/zakony/zakonPar.jsp?page $=0 \&$ idBiblio=39560\&recShow $=1 \& \mathrm{nr}=513 \sim 2 \mathrm{~F} 1991 \& \mathrm{rpp}=15 \#$ parCnt

[12] Zákon č. 89/2012 Sb., Občanský zákoník. Ministerstvo spravedlnosti [online]. 22. června 2013 [vid. 22. června 2013]. Dostupné z: http://obcanskyzakonik.justice.cz/tinymcestorage/files/odborne_texty/NOZ\%20interaktiv.pdf 
[13] Zákon č. 90/2012 Sb., Zákon o obchodních korporacích, Ministerstvo spravedlnosti [online]. 22. června 2014 [vid. 22. června 2014]. Dostupné z: http://obcanskyzakonik.justice.cz/fileadmin/ZoK_interaktiv.pdf 